\title{
REPERTORIOS EXTRAVERBALES EN LA COMUNICACIÓN LITERARIA*
}

\author{
José Romera Castillo
}

(UNED, Madrid)

Día 12 de octubre de 1492. Unos perdidos navegantes llegan a una ignota tierra. Aquel día viernes, Colón desciende de su nave, toma posesión de la «isleta de los lucayos» ${ }^{1}$, intercambia una serie de cosas

* Este trabajo recoge la sesión plenaria impartida en el VII Congreso Internacional de la Asociación de Lingüística y Filología de la América Latina (ALFAL), celebrado en Tucumán (Argentina), del 7 al 11 de septiembre de 1987, cuyas actas, por diversas circunstancias, no se han publicado. Se edita tal cual fue expuesto en dicho año. Añadiré que posteriormente he dedicado otros dos trabajos al tema: «Gestos y ojos "hablan" en Sonata de Primavera», Revista de Estudios Hispánicos (Universidad de Puerto Rico) XVI (1989), 45-51 (en el número monográfico, Valle-Inclán. Homenaje, coordinado por mí) y «Sistemas no verbal y verbal en literatura», Face. Revista de Semiótica e Comunicação (São Paulo, Brasil) 1 (1991), 75-91. Para una actualización sobre el tema remito a Fernando Poyatos, «Paralenguaje y sonidos extrasomáticos en la novela: perspectivas semiótico-comunicativas a través de los estudios de comunicación no verbal», en J. Romera, A. Yllera y M. García Page (eds.), Semiótica(s). Homenaje a Greimas (Actas del III Seminario Internacional de Literatura y Semiótica), Madrid: Visor Libros, 1994, 141-155. La editorial Istmo de Madrid publicará, en breve, tres volúmenes de Fernando Poyatos sobre La comunicación no verbal.

1 Colón, Cristóbal: Diario del Descubrimiento (Estudios, Ediciones y Notas por Manuel Alvar). Las Palmas: Ediciones del Exmo Cabildo Insular de Gran Canaria, 1976, 2 vols. Citaré por la edición actualizada contenida en el vol. segundo. 
con la mucha gente que allí «se ayuntó» y se produce el primer contacto comunicativo con los indígenas. «Yo - escribe el Almirante- vide a algunos que tenía señales de feridas en sus cuerpos, y les hize señas qué era aquello, y ellos me amostraron cómo allí venían gente de otras islas que estaban acerca y los querían tomar y se defendían» (págs. 5253). Desde el primer momento, lo no verbal va a tener una importancia capital. La comunicación entre los «hombres venidos del cielo» y los nativos era imposible por la disparidad de códigos linguiísticos. El arma salvadora estará en las simples señas, ya que como afirma el jefe de la expedición "por lengua no los entiendo».

In principio erat verbum. Ahora, además del verbum, es el cuerpo. La tiranía del logos, por influencias griegas y sobre todo cristianas, comparte espacios con otros elementos. El cuerpo está de moda; de ahí que el hombre de hoy - y no digamos la mujer - cuide tanto la salud, se esmere tanto en estar en forma. Antes estudiaba el cuerpo fundamentalmente la medicina, ahora lo hace la etnología, el psicoanálisis, la fenomenología, la sociología, etc., hasta llegar al teatro, muy especialmente desde Grotowski, para el que la expresividad corporal es una de las reinas de la escena. Según P. Bourdieu (1977:51) «el cuerpo funciona como un lenguaje mediante el cual, más que expresarse, el individuo es expresado, un lenguaje de la naturaleza con el que se traiciona lo más oculto y a la vez más verdadero, por ser lo menos conscientemente controlado y controlable, y que contamina y determina con sus mensajes percibidos y no advertidos todas las expresiones intencionales, empezando por la palabra ${ }^{2}$. Estamos, desde nuestro punto de vista, en busca del cuerpo perdido. Estamos - y queremos- semiologizar el cuerpo para ver la capacidad y fuerza que tienen algunos de sus miembros en la producción y manifestación de múltipes signos en la comunicación entre los seres vivos, tanto en el hombre como en los animales, como se ha encargado de estudiar, para esta última especie, la zoosemiótica.

Como constatación objetiva -y para tranquilidad de los lingüistassabemos que la palabra es el vehículo más importante que usan los hombres para comunicarse, pero no siempre ésta es la clave en la interacción de mensajes, como lo demuestra el caso siguiente: «Narciso y Goldmundo Teufel, dos marinos hermanos gemelos, naufragaron juntos y fueron a parar cada uno a una de las dos islas también gemelas. Aunque ambos tenían una voz potente, entrenada contra el fragor del mar en cientos de tempestades, no podían comunicarse verbalmente.

2 Vid. además J. Fast (1971) y Michel Bernard (1972). 
Afortunadamente abundaban por allí los delfines, y Narciso los adiestró para que transmitiesen mensajes. Como es sabido, los delfines son seres altamente inteligentes y se negaron rotundamente a transmitir los mensajes de Narciso por considerarlos muy estúpidos» ${ }^{3}$.

La agudeza y arte de ingenio del hombre ha producido muchísimos lenguajes. Desde el articulado u oral al escrito, al del mimo, la danza, el de los ciegos, el de los sordos, el del silbido (practicado también por los habitantes de la isla canaria de la Gomera, el célebre silbo gomero, estudiado por Ramón Trujillo), el del abanico y tantísimos otros que podríamos enumerar. Fíjense hasta dónde puede llegar su inventiva que, además del ordenador, creó un sofisticado y evocador lenguaje: el del pañuelo, que llegó a plasmarse en la obra anónima, El secretario de los amantes o El libro de enamorados ${ }^{4}$. He aquí algunos de sus signos: «Si se pasa el pañuelo por la frente es que se duda del galán; si se apoya en la mejilla derecha es que no, y en la izquierda que sí. Si se agita con la mano izquierda quiere decir "te amo", y si se hace con la derecha "te odio". Mensajes negativos son sacudirse el vestido con él ("te aborrezco"), retorcerlo con ambas manos ("indiferencia", aunque parece mucho trabajo para expresar la ausencia de sentimientos) y jugar con él ("te despredio"). Aunque se trataba de sociedades más reducidas, y por ello controlables, había fórmulas para informar de que el corazón de la dama no era libre: retorcerlo con la mano derecha ("amo a otro"), arrollarlo al dedo índice ("estoy comprometida") o al anular ("soy casada"). No estoy seguro de que los amantes miopes pudieran captar estas sutiles variaciones. Pasar el pañuelo por los ojos significa que los comunicantes son expiados. Doblarlo lentamente equivale a "tengo que hablarte". Llevarlo cogido de una punta indica "sígueme". Mirar una punta significa que se ha leído la carta del pretendiente y meterlo en el bolsillo anuncia que se escribirá al amante. $\mathrm{El}$ amante queda identificado con el pañuelo desde el momento en que envolverse con éste la mano expresa "soy tuya". Retorcerlo con la mano izquierda (el pañuelo, no el amante) simboliza la sentencia final: "Hemos acabado".» Por ello, en adelante, antes de sacar el pañuelo o el aséptico kleenex apercíbanse de cómo lo usan.

Son por tanto muchos y muy variados los códigos empleados en la comunicación humana. Sin restar ni un ápice de importancia al lenguaje que estoy empleando en este momento, sin embargo hay que tener muy claro que este sistema lingüístico o verbal no es el único que se

3 Tomo el caso de Josep-Vicent Marqués (1987).

4 Barcelona: Ramón Sopena, 1983. La cita que sigue corresponde al mismo artículo de Marqués (1987). 
usa en la interacción de los seres racionales. Lo que importa, en definitiva, es que el hombre por medio de una serie de sistemas -o lenguajes ¿por qué no emplear el plural?- lo que ha pretendido, pretende y pretendrá es salir de la incomunicación.

Comunicar es transmitir informaciones a través de unos medios - unos signos- más o menos simbólicos de representación. Ahora bien, ¿cómo es posible que una persona entienda a otra, es decir, que entienda su habla y descubra sus creencias y valores? Una de las respuestas a la compleja pregunta la proporciona el filósofo norteamericano Donald Davidson que trabaja actualmente en la teoría de la interpretación y que intenta unir el campo de la filosofía del lenguaje con el de la teoría de la acción (campos expuestos en sus obras Verdad e interpretación y Acciones y acontecimientos). Para el citado investigador, «una persona que no tuviera contacto con otras no tendría un concepto de realidad objetiva. Captar la idea de un mundo independiente de nuestro pensamiento es tener la idea de una realidad intersubjetiva que es compartida por otros. Saber que uno comparte un mundo con otros requiere leguaje». Queda lejos el aserto de Hamlet: «Oh Dios, podría estar encerrado en una nuez y considerarme rey del infinito espacio». Pero ¿cómo concebir esta relación con el otro, es decir, el comportamiento social colectivo? ¿Intentando postular, como ha hecho la filosofía tradicional, una mente colectiva y una conciencia colectiva igualmente mítica? o ¿reduciendo toda la teoría de la intencionalidad a las intenciones presididas por la representación del yo? La respuesta, a mi modo de ver, nos la proporciona otro de los grandes filósofos de la actualidad, John Searle, tras hacerse él mismo otra interrogación: «¿cómo puede darse el caso de que haya realmente comportamiento colectivo como algo distinto de la suma de comportamientos individuales si la sociedad consta exclusivamente de individuos? Mi respuesta es que el comportamiento colectivo puede existir porque tenemos lo que técnicamente se denominan intenciones, que están protagonizadas por la representación del sujeto nosotros además de las que están presididas por la representación del sujeto yo. El soporte de unas y otras es el cerebro de los individuos» ${ }^{5}$.

El resultado de esta suma de factores es sencillamente la comunicación, un lugar de encuentros, una necesidad de contarse a los demás.

5 Las tesis de los dos filósofos norteamericanos, profesores de la universidad de Berkeley (California), fueron expuestas en el Simposio Internacional de Filosofía de la Acción y la Comunicación, celebrado en Madrid, en marzo de 1987. Tomó las citas de la entrevista con Manuel Garrido de los dos investigadores aparecida en el periódico madrileño El País, sábado 28 de marzo (1987), 33. 
Para ello el hombre utiliza una serie de sistemas de comunicación que, en principio, los podemos clasificar como verbales y no verbales (y no entro en la polémica sobre la disignación de esta segunda clase). Ambos pueden ser vocales y no vocales.

Así la lengua hablada sería un sistema verbal, vocal; la lengua escrita, el código Morse, etc. serían verbales no vocales; una exclamación de miedo, un grito, etc., serían no verbales vocales: y los gestos, posturas, etc. serían no verbales y no vocales. Después volveremos sobre ello.

No es muy atinado afirmar, como se hace frecuentemente, que los estudios de la comunicación no verbal no tienen más de una treintena de años. Baste recordar, por ejemplo, los análisis que durante los siglos XVI y XVII se hicieron sobre la elocuencia muda, insertos la mayoría de las veces en obras y tratados filosóficos, como los de Bruno o la Scienza nuova, estudiados por G. Gocchiara $(1977)^{6}$, que llegan hasta las observaciones que Charles Darwin (1955), en The Expression of Emotions in Man and Animals, hizo sobre el significado de las expresiones faciales; los estudios de W. Wundt (1973), en 1870, o las anotaciones de Sapir (1962) en 1920, por citar unos cuantos botones de muestra. Lo que sí es cierto es que, en los últimos años, el auge de los estudios sobre la comunicación no verbal ha sido muy numeroso, alcanzando un alto nivel científico y sistemacidad que antes no tenían. Ahí están, por ejemplo, los trabajos ya clásicos de Ray L. Birwhistell (1952, 1973), M. L. Knapp (1982), P. Bouissac (1973), D. Efron (1972), E. T. Hall (1959, 1966, 1976), A. Kendon $(1975,1981)$, los trabajos de T. A. Sebeok y los del Research Center for Language and Semiotic Studies $^{7}$, de la universidad de Indiana, en Bloomington, que dirige, y los del español Fernando Poyatos —del que tendremos ocasión de hablar-, entre los muchos nombres que se podrían citar. Quienes estén interesados en el tema pueden acudir a los estudios históricos y bibliográficos de M. Davis (1972), cuyas 931 referencias bibliográficas abarcan los años 1900 a 1970; y M. Davis y J. Skupien (1982), con

6 Texto aparecido en 1930.

7 Son muchos los trabajos de T. A. Sebeok sobre la comunicación no verbal en los animales y en los seres racionales. Bajo su dirección el Research Center for Language and Semiotic Studies ha preparado una serie de manuales: $A$ Handbook on Nonverbal Communication in the Teaching of Foreing Languages, de Sahnny Johnson; $A$ Handbo$o k$ on Nonverbal Communication for the Teachers of English as a Foreing Language, de S. Johnson, O. Najjar y T. Strout; $A$ Handbook of Nonverbal Communication for Theachers of Japanese, de S. Johnson y C. Harshberger; A Handbook of Nonverbal Communication for Teachers of Arabic as Spoken in the Area of the Gulf of Arabia, de S. Johnson y J. Hengst; etc. 
1411 fichas de libros y artículos escritos en diferentes lenguas (inglés, alemán, español, francés, italiano, portugués y flamenco), para los años $1971-1980^{8}$.

Sobre el área iberoamericana se han llevado a cabo también interesantes estudios sobre la comunicación no verbal. Sin pretender hacer un estado de la cuestión que, sin duda, es necesario realizar, habría que señalar los trabajos de Charles E. Kany (1960) que estudia 42 gestos de la América hispana; Robert L. Saitz (1972), que se fija en los gestos colombianos en comparación con los de los Estados Unidos; R. L. Gorden (s.a., 1974) que analiza gestos colombianos y de América Latina; G. M. Zilio (1960) que estudia el lenguaje de los gestos en el Río de la Plata; y los trabajos para España de Fernando Poyatos $(1985)^{9}$, Esther Torrego $(1971)^{10}$, Sánchez de Zavala (1973), Sebastián Serrano (1980), etc. Creo que es muy interesante el estudio realizado por Mónica Rector y Aluizio R. Trinta $(1985)^{11}$, en el que además de ofrecer un repertorio de la gestualidad brasileña, hacen una introducción general a la comunicación no verbal y un estado de la cuestión de lo que se ha escrito sobre ella en portugués.

La relación bibliográfica podría continuar, repito que no pretendo dar exhaustividad a este apartado, pero no quisiera terminar sin referirme a un estudio muy curioso y un tanto desconocido. José Moreno Villa (1940), poeta español de la generación del 27, exiliado en México, en su obra Cornucopia de México ${ }^{12}$, interpretó algunos gestos mexicanos referidos al dinero, acción de gracias, unidad mínima de tiempo y volumen y altura de seres humanos, animales y cosas, coincidiendo Kany con él sólo en dinero ${ }^{13}$.

8 Una escueta, pero buena, selección bibliográfica sobre la comunicación no verbal, puede encontrarse en Tullio de Mauro (1986: 14-16). Cf. además A. Walfgang (1984) y la más genérica de W. Nöth (1985) (obra en la que se ofrece una historia del desarrollo de la semiótica, algunos fundamentos teóricos y su aplicación a diversos campos: lo verbal, lo no verbal, la estética, etc.); además de artículos en revistas como Semiotica, etc.

9 Una bibliografía de sus investigaciones más importantes sobre el tema se encuentra al final de su trabajo, «Antropología literaria: la narración como fuente interdisciplinar de signos culturales sensibles e inteligibles» (Poyatos, 1985).

10 Además de la tesis doctoral, Aportación al estudio de los gestos y sus relaciones en el español hablado, presentada en la Universidad Complutense de Madrid en mayo de 1974.

11 Obra que he tenido muy en cuenta para la redacción de este apartado.

12 Una segunda edición apareció en México: Porrúa y Obregón, en 1952, en la serie "México y lo mexicano".

13 Sería conveniente realizar una nómina de las obras que, sobre el tema, se han traducido al español. Señalaré que la editorial Paidós, en Argentina, publica la colección Biblioteca de técnica y lenguajes corporales; y en Barcelona, Paidós Comunicación; etc. 


\section{PARALENGUAJE}

Fernando Poyatos, uno de los especialistas más importantes de la comunicación no verbal, ha propuesto la idea de la antropología literaria como campo independiente, pero complementario, de otras parcelas del saber (la misma antropología, la crítica literaria, la sociología, la psicología, la lingüística, la semiótica, los estudios sobre la comunicación no verbal, etc.). La tesis del investigador español, docente en la universidad canadiense de New Brunswick, es que a través de los repertorios extraverbales de los personajes (sobre todo en la novela, el cuento y la épica) se manifiestan muy claramente «patrones culturales y universales». Las literaturas narrativas de las distintas culturas, antes de que existiese el cine y las técnicas magnetofónicas, «no sólo "describen", sino que "hablan de" muchos comportamientos e ideas típicos de esas culturas, y por tanto son superiores a cualquier otra forma de representación» (Poyatos, 1985: 373), como la pintura o la escultura. La «cultura» es comunicación -insiste el citado investigador - «bien estrictamente humana [directa, en la que operan los sistemas somáticos, o diferida, como los intercambios epistolares y la literatura escrita, o a través de mensajes registrados acústica o gráficamente (todos ellos canalizados somáticamente también)] o no humana, por medio del mundo objetual del entorno (modificado, construido o natural) y de las especies animales adaptadas a cada cultura». Por ello - apostilla- «El narrador, sobre todo el novelista, dota a sus personajes de características somáticas que, consciente o inconscientemente por parte de él, les permiten comunicarse entre ellos en un mundo ficticio lo mismo que funcionan en el real, según una serie de factores biofísicos-psicológicos y socioeconómicos-culturales. Y estas descripciones nos comunican a nosotros, los lectores, no sólo personalidades e idiosincracias elaboradas en la mente del autor, sino una cultura concreta, quiera él o no, lo mismo que la revelan sus sistemas inteligibles» (Poyatos, 1985: 374).

Toda cultura está compuesta de una serie de signos y, por tanto, puede ser analizada desde un punto de vista de semiótico. De ahí que para examinar la comunicación humana - y la literatura es una de sus formashaya que partir de lo que Poyatos denomina la Estructura Triple Básica ${ }^{14}$, que está compuesta por el lenguaje verbal, el paralenguaje y la kinésica ${ }^{15}$.

14 Aunque el investigador ha reincidido sobre ella en varios de sus trabajos, conviene ver Poyatos (1983).

${ }_{15}$ Poyatos prefiere la grafía $k$ para kinésica en lugar de la $c$ (cinésica, que emplean otros autores) para evitar la ambigüedad con otros lexemas e internacionalizar más el término. 
La literatura es un lenguaje verbal y aún más es un lenguaje verbal específico, sui generis, como han demostrado Jakobson, Lotman o Lázaro Carreter ${ }^{16}$. El creador literario en su comunicación a distancia utiliza la palabra escrita fundamentalmente (aunque también pueda emplear la oral) y otro instrumento expresivo cual es la puntuación que tan importante es para poner de manifiesto ciertos aspectos que su escritura no puede reproducir. Así - afirma Poyatos - los signos de exclamación e interrogación pueden duplicarse, triplicarse, etc., o combinarse; el guión (-) y los puntos suspensivos (...) se utilizan para representar indistintamente en el diálogo la elipsis producida por una interrupción, la duda o el silencio provocado por una reacción emocional; con cursivas se da énfasis, y se-pa-ran-do-las-pa-la-bras se indican el énfasis y el ritmo entrecortado del discurso acelerado; con MAYÚSCULAS se intenta transmitir el volumen muy alto con distintos matices; y se usan apóstrofes para representar el habla rural apocopada y sincopada (más apropiadamente en inglés). Pero, más o menos, esto es todo cuanto hay al alcance del escritor» (Poyatos, 1976: 359, nota 8) ${ }^{17}$.

Pero además del lenguaje verbal en la literatura, como en el lenguaje usual, se reproducen una serie de actividades no verbales que a continuación describo y que luego intentaré explicar.

El segundo elemento de la Estructura Triple Básica de la comunicación humana es el paralenguaje, constituido por todas aquellas modificaciones que sufre la palabra (la del lenguaje verbal, claro) y por las construcciones sonoras no léxicas. Estamos, por lo tanto, ante unas manifestaciones no verbales, pero vocales. Poyatos (1976: 360, nota 9) lo define como «las cualidades no verbales de la voz, modificadores y sonidos producidos o condicionados en las zonas comprendidas entre las cavidades supraglotales (desde los labios y los orificios nasales hasta la faringe), la cavidad laríngea y las cavidades infraglotales hasta los músculos abdominales que usamos consciente o inconscientemente reforzando o contradiciendo el mensaje lingüístico, kinésico o proxémico, bien simultáneamente con la palabra o alternando con ella». El citado investigador distingue cuatro categorías paralinguiísticas: las cualidades primarias (timbre, tono, entonación, volumen, etc); los modificadores calificadores (control glotálico, velar, laríngeo, labial y respiratorio, etc.); los modificadores diferenciadores (cuchicheo, lloro,

16 F. Lázaro Carreter, Estudios de poética (Madrid: Taurus, 1976); y Estudios de Lingüistica (Barcelona: Crítica, 1980).

17 Ver además Poyatos (1981). Aunque algunas inflexiones de la voz puedan representarse por los signos prosódicos, sin embargo no entran, en sentido estricto y según Poyatos, en el paralenguaje. 
risa, tos, etc.); y los alternantes (articulados ya sean vocálicos o consonánticos; inarticulados y pausales). Las tres primeras categorías no son representables en la escritura, por lo que el escritor tendrá que poner en funcionamiento su numen para describirlos con competencia literaria; en cambio los alternantes son formas paralingüísticas representables (Posst, Uf!, Hum, etc.) (Poyatos, 1976: 360).

Como por razones de espacio y tiempo no puedo detenerme en ejemplificar cada uno de estos repertorios paralingüisticos, me detendré un poco en uno de los modificadores diferenciadores: la tos como instrumento de comunicación, que Leopoldo Alas, Clarín, expone en uno de sus cuentos, El dúo de la $\operatorname{tos}^{18}$. La acción se desarrolla en un balneario indefinido en el norte de España. Estamos en el gran hotel del «Águila». Es de noche. Dos seres - dos bultos, nos dice el autor-, un hombre de treinta años y una mujer (extranjera) de veinticinco, enfermos de tuberculosis, con perspectivas de muerte, van al balneario para mejorar su estado. Instalados en el tercer piso del hotel, él en cuarto 36 y ella en el 32 -separados por la habitación 34 que no ocupa nadie - van a salir momentáneamente de su soledad por medio de la ilusoria comunicación a través de la tos enfermiza y lastimera. Nada de palabras sólo toses.

El bulto del 36 está fumando en balcón de su cuarto y «siente una angustia en la soledad del silencio y las sombras» (pág. 118). Pero de pronto:

\begin{abstract}
«...como si fuera un formidable estallido, le hace temblar una tos seca, repetida tres veces como canto dulce de codorniz madrugadora, que sueña a la derecha, dos balcones más allá. Mira el del 36, y percibe un bulto más negro que la oscuridad ambiente, del matiz de las gabarras de abajo. "Tos de enfermo, tos de mujer"» (pág. 118).
\end{abstract}

Tras lo cual se recoge en su cuarto. La mujer quería compañía. Dos horas y media después, el del 36 «empezó a resonar, como bajo la bóveda de una cripta, una tos rápida, enérgica, que llevaba en sí misma el quejido ronco de la protesta» (pág. 119). «Y tosía, tosía, en el silencio lúgubre de la fonda dormida... De pronto creyó oír como un eco lejano y tenue de su tos. Un eco... en tono menor. Era la del 32» (pág. 120):

18 Citaré por la edición de Carolyn Richmond: Lepoldo Alas, Treinta relatos, Madrid: Espasa-Calpe, 1983, 117-123. El motivo de la tos fue usado por Clarín en otras ocasiones (Sinfonía de dos novelas, Benedictino, etc.). Me he ocupado más extensamente de este cuento en «Espacio y tiempo, elementos connotadores en El dúo de la tos de Clarín", Letras de Deusto, 32 (1985), 199-206. 
1. La del 32 tosía, en efecto; pero su tos era... ¿cómo se diría? más poética, más dulce, más resignada. La tos del 36 protestaba; a veces rugía. La del 32 casi parecía un estribillo de una oración, un miserere; era una queja tímida, discreta, una tos que no quería despertar a nadie. El 36, en rigor, todavía no había aprendido a toser, como la mayor parte de los hombres sufren y mueren sin aprender a sufrir y a morir. El 32 tosía con arte; con ese arte del dolor antiguo, sufrido, sabio, que suele refugiarse en la mujer.

Llegó a notar el 36 que la tos del 32 le acompañaba como una hermana que vela; parecía toser para acompañarle.

Poco a poco, entre dormido y despierto, con un sueño un poco teñido de fiebre, el 36 fue transformando la tos del 32 en voz, en música, y le parecía entender lo que decía, como se entiende vagamente lo que la música dice (págs. 120-121).

2. La tos del 36 le dio lástima y le inspiró simpatía. Conoció pronto que era trágica también. «Estamos cantando un dúo», pensó; y hasta sintió cierta alarma del pudor, como si aquello fuera indiscreto, una cita en la noche. Tosió porque no pudo menos; pero bien se esforzó por contener el primer golpe de tos.

La del 32 también se quedó medio dormida, y con algo de fiebre; casi deliraba también; transportó la tos del 36 al país de los ensueños, en que todos los ruidos tienen palabras. Su propia tos se le antojó menos dolorosa apoyándose en aquella varonil que la protegía contra las tinieblas, la soledad y el silencio. «Así se acompañarán las almas del purgatorio.» Por una asociación de ideas, natural en una institutriz, del purgatorio pasó al infierno, al de Dante, y vio a Paolo y Francesca abrazados en el aire, arrastrados por la bufera infernal (pág. 121).

3. De modo que lo que en efecto le quería decir la tos del 32 al 36 no estaba muy lejos de ser lo mismo que el 36, delirando, venía como a adivinar:

«¿Eres joven? Yo también. ¿Estás solo en el mundo? Yo también. ¿Te horroriza la muerte en la soledad? También a mí. ¡Si nos conociéramos! ¡Si nos amáramos! Yo podría ser tu amparo, tu consuelo. ¿No conoces en mi modo de toser que soy buena, delicada, discreta, casera, que haría de la vida precaria un nido de pluma blanda y suave, para acercarnos juntos a la muerte, pensando en otra cosa, en el cariño? ¡Qué solo estás! ¡Qué sola estoy! ¡Cómo te cuidaría yo! ¡Cómo tú me protegerías! Somos dos piedras que caen al abismo, que chocan una vez al bajar y nada se dicen, ni se ven, ni se compadecen... ¿Por qué ha de ser así? ¿Por qué no hemos de levantarnos ahora, unir nuestro dolor, llorar juntos? Tal vez de la unión de dos llantos naciera una sonrisa. Mi alma lo pide; la tuya también. Y con todo, ya verás cómo ni te mueves ni me muevo."

Y para la enferma del 32 oía en la tos del 36 algo muy semejante a lo que el 36 deseaba y pensaba:

«Si, allá voy; a mí me toca; es natural. Soy un enfermo, pero soy un galán, un caballero; sé mi deber; allá voy. Verás qué delicioso es, entre lágrimas, con perspectivas de muerte, ese amor que tú sólo conoces por libros y conjeturas. Allá voy, allá voy... si me deja la tos... ¡esta tos!... ¡A Ayúdame, ampárame, consuélame! Tu mano sobre mi pecho, tu voz en mi oído, tu mirada en mis ojos...» (págs. 122-123).

El dúo de la tos es un cuento de soledad, la soledad de dos seres innominados, con gran anhelo de la comunicación, de compañía, aunque sólo sea en la ilusión de una noche de verano. Comunicación que logran a través de la tos y que ha permitido a Clarín plasmar un realismo psicológico altamente significativo. 


\section{KINÉSICA}

La kinésica, iniciada como ámbito científico por Ray L. Birdwhistell, es el tercer componente de la Estructura Triple Básica de la comunicación humana. F. Poyatos (1976: 362, nota 12) la define como «el estudio sistemático de los movimientos y posiciones corporales de base psicomuscular, aprendidos o somatogénicos, de percepción visual, visualacústica, táctil y cinestésica, que aislados o combinados con las estructuras lingüístico-paralingüísticas y con el contexto situacional poseen valor comunicativo, sea consciente o inconsciente». El mismo investigador distingue entre gestos (el movimiento corporal hecho con la cabeza, el rostro u otros miembros; la mirada, la sonrisa, los gestos de amenaza, etc.); maneras (actividades corporales aprendidas y socialmente institucionalizadas: modos de saludar, utilizar los cubiertos, aplaudir, etc.); y posturas (posición del cuerpo, más estática que los gestos y las maneras, que es usada secundariamente como instrumento de comunicación; posición de descanso, manos atrás al andar, etc.).

La actividad kinésica es de suma importancia en la interacción entre las personas y, también, la tiene - y mucha- en la creación literaria, solamente que en ésta el escritor se tiene que esforzar en plasmarla en su escritura a través de los signos gráficos. Pero es muy importante para poner de manifiesto su competencia literaria y para lograr una mayor profundización psicológica en la descripción de sus personajes. A veces sirve para reforzar el lenguaje verbal y otras para dar con el significado global de un texto. Las actividades kinésicas vienen a menudo explícitamente expresas en las obras literarias. Veamos algún ejemplo.

En el Diario de Colón, como he tenido ocasión de ocuparme ${ }^{19}$, lo kinésico va tener mucha importancia. En treinta ocasiones se nos nombran las palabras señas, señales y ademanes. Era el único modo que tenían, en principio, españoles e indios para comunicarse:

«Partió de allí para Cuba, porque por las señas que los indios le daban de la grandeza y del oro y perlas d'ella, pensaba que era ella, conviene a saber, Cipango" (pág. 85).

«...Dixo un indio por señas que el almáciga era buena para cuando les dolía el estómago» (pág. 99).

19 J. Romera Castillo, «Rasgos kinésicos en el Diario de Ctistóbal Colón», en Actas del II Congreso Internacional sobre Literatura Hispánica. Reyes Católicos y Descubrimiento (Barcelona: PPU, 1989, 115-124). 
Pero fíjense en algo curioso y significativo: si fragmentamos esa treintena de citas explícitas sobre la gestualidad, en once ocasiones las señas están relacionadas con el ansiado oro; cinco con lo geográfico; cuatro, con lo corporal; tres, con las riquezas y las preciadas especias; dos, con la comunicación de los indios entre sí; y una con el poder de los reyes de Castilla, la oración, las cosas maravillosas, el tiempo y los ademanes de los indios, respectivamente. Como los números cantan y no hay más cera que la que arde, objetivamente y por lo que se refiere a los gestos explícitos, en el Diario sí es oro todo lo que reluce.

Otro dato más del Diario: de las treinta veces —alguna se me ha podido escapar- en las que aparece explícitamente la comunicación kinésica en veinticuatro son los aborígenes los que dirigen a los españoles; en dos, los indios se comunican entre sí; en una, la situación es ambigua; mientras que Colón se dirige por señas a los nativos concretamente (en las veinticuatro ocasiones anteriores se presupone que también lo haría, pero no se nos dice) en tres ocasiones. Una para preguntarles si hacían oración:

«Yo pensé que era templo, y los llamé y dixe por señas si hazían en ella oración; dixeron que no» (pag. 132).

Otra, para darles a entender el poder de los Reyes Católicos:

«El Almirante les dixo por señas que los Reyes de Castilla mandarían descubrir a los caribes y que a todos se los mandarían traer las manos atadas» (pág. 177).

Y la tercera, más ambigua, para demandar dónde se cogía el oro:

«...Y como siempre trabajase por saber donde se cogía el oro, preguntaba a cada uno, porque por señas ya entendía algo» (pág. 182).

Una tríada perfectamente armónica en la que lo religioso, lo político y lo material tienen — como debía de ser-complida presencia.

Como ven la presencia o ausencia de las conductas kinésicas en los textos literarios no es tan inocente. El escritor, consciente o inconscientemente, plasma en su escritura una serie de indicios y el lector, o 
mejor el crítico, no tiene otra opción que cuantificarlos y tenerlos en cuenta como una varilla más de abanico - ipero no la única! - a la hora de interpretar la significación global de las obras literarias ${ }^{20}$.

De la importancia de los gestos creo que nadie duda y tampoco es necesario que me detenga a enfatizarla. Baste, simplemente, el siguiente ejemplo que evoca Antonio Gala:

«Entre Granada y Jaén hay una finca espléndida, que perteneció al matador Bombita. Cuando las agitaciones campesinas andaluzas, con horcas y hoces se presentó un grupo amenazador ante la casa. Salió el maestro, viejo e impresionante aún; miró a los campesinos en los ojos, y, sin decir palabra, se desabrochó los pantalones y se los echó abajo. Aparecieron su vientre y sus muslos acribillados por las cicatrices. Los hombres de mirada torva comprendieron el gesto y su mensaje, abatieron los rebeldes utensilios, y se alejaron» 21

Gestos que, en ocasiones, adquieren un simbolismo manifiesto. Como nos cuenta el novelista español Jesús Ferrero en uno de sus últimos relatos breves:

«[En el Retiro] Manuel arrancó del suelo una de esas hierbas que crecen en los claros, afiladas como bisuteríes, y miró con complacencia a Lola.

Los indios de América del Norte se rozan, las muñecas ensangrentadas cuando quieren hacerse hermanos de sangre... - dijo él一, y se acercó el frágil filo a su muñeca, después a la de Lola, y se rozaron las heridas mientras se besaban» 22 .

El cuerpo, en definitiva, es un hablador. El rostro es la enseña del ser humano y a través de la descripción de sus movimientos el narrador nos da claves de la personalidad de sus actores; al igual que por medio de la plasmación de otros movimientos corporales. He aquí cómo describe Juan Goytisolo a Fidel Castro en su obra En los reinos de taifa:

«Su rostro es vivo, móvil, astuto: vigila con el rabillo del ojo el efecto de sus palabras y a veces le pillas una expresión matrera o esquiva, instintivamente suspicaz... En adelante, le verás... saltando del jeep o encaramado en la tribuna de sus discursos, antebrazo magistral, índice brujo, impartiendo lecciones de cosas con su extrema voluntad didascálica» ${ }^{23}$.

20 Las diferentes tipologías gestuales las ejemplifiqué en el Diario en el trabajo citado en la nota anterior.

21 A. Gala «Toreros», El País Semanal, 531, domingo 14 de junio (1987), 150. Entrega de la serie Dedicado a Tobias.

22 J. Ferrero, Besos en tu suéter manchado de vino, aparecido como cuadernillo aparte en El País Semanal, $\mathrm{n}^{\circ}$ 536, domingo 19 de julio (1987), 11.

23 J. Goytisolo, En los reinos de taifa (Barcelona: Seix Barral, 1986, 173). 
Las manos son también muy importantes en la kinésica. Muchos ejemplos de ello podemos encontrar en la obra de Julio Cortázar. El escritor argentino lo reconoce: «La mano ha sido una cosa muy mágica para mí. Las manos funcionan mucho en mis cuentos. Incluso hay uno, Estación de la mano, en que una mano entra por una ventana y se hace amiga de un individuo, pero él, de tanto verla jugar con un puñalito, le toma miedo y la mano se da cuenta y se va. Ahí aparece ya la obsesión de la mano. Quizás venga del hecho de que una vez una de esas primeras mujeres que uno tiene en la vida me dijo que "lo único verdaderamente interesante en tí son las manos; tus manos tienen más personalidad que tu cara". Y me marcó eso». Obsesión - y lenguaje- que aparece a través de sus escritos tanto en poesía (Último Round, Pameos, etcétera.) como en su narrativa (Rayuela, capítulo 62,76 , etc.) ${ }^{24}$.

\section{POLISEMIA GESTUAL}

A veces un mismo gesto o gestos semejantes pueden significar mensajes diferentes. Todos sabemos que el lenguaje gestual es mucho más internacional que el de las simples palabras para entenderse con hablantes de otras lenguas; pero también todos conocemos la ambivalencia y, en ocasiones, la perplejidad al comprobar que en culturas diferentes los gestos adquieren una significación variada. Por ejemplo, en Japón el contacto visual es algo clave para la manifestación de lo que alguien siente hacia otra otra persona, pero cuanto menos se utilice mejor. «Lo que para un occidental es una honesta mirada directa a los ojos, para el oriental es una falta de respeto y una afrenta personal. Incluso al estrecharse las manos o al hacer una reverencia -y especialmente durante una conversación-, sólo se considera correcta alguna mirada ocasional» ${ }^{25}$. El cabeceo en la mayoría de los países significa $s i$, mientras que en Bulgaria y Grecia, por ejemplo, significa no. Hacer un círculo con los dedos, aceptado como el signo norteamericano de OK («está bien»), se considera vulgar u obsceno en Brasil, está mal visto en la Unión Soviética o Grecia, en Japón significa «dinero» y en otros lugares «cero» $\mathrm{o}$ «sin valor», etc.

24 Datos que tomo de Andrés Amorós, editor de Rayuela (Madrid: Cátedra, 1984, 551 , nota 1).

25 «Cuando un guiño deja de ser inocente», El País, domingo 2 de noviembre (1986), sección «Domingo», pág. 11. Las referencias que siguen y otras se pueden documentar en el resumido diccionario internacional de gestos que Parker Pen Co. ofrece en el artículo. 
Cada cultura tiene unos determinados usos y costumbres. De ahí que podemos hablar - según la terminología de Fernando Poyatos (1985) - de culturemas que serían cualquier porción de actividad cultural comprendida - sensorial e intelectualmente - en signos de valor simbólico que una sociedad determinada combina en asociaciones de mayor o menor complejidad y cuya reunión permite el establecimiento de estructuras culturales. Veamos en el ámbito de la literatura escrita dos ejemplos al respecto.

El primero, muy clásico y muy conocido por todos. Se trata De la disputación que los griegos e los romanos en uno ovieron de el Libro de Buen Amor ${ }^{26}$. Casi en el pórtico del libro, el Arcipreste, después de los Gozos de Santa María, a manera de prólogo justificatorio de las burlas de la obra, se encarga de dejar bien clara su intencionalidad:

(46) Entiende bien mis dichos e piensa la sentençia: no $m$ 'contesca contigo como al doctor de Greçia con el ribald romano e su poca sabiençia, quando demandó Roma a Greçia la çiençia.

Y empieza el exemplo sobre cuyas fuente y desarrollo en la literatura han tratado, Lecoy, Spitzer y Deyermond, entre otros ${ }^{27}$. Recordemos brevemente el relato. Los romanos no tenían leyes del derecho y fueron a pedírselas a los griegos, a lo que respondieron éstos «por se excusar» que no las merecían por no poderlas aquéllos entender; ahora bien, si las querían usar, antes tendrían que practicar con los sabios griegos el ejercicio escolar de la disputatio. Los romanos respondieron que «les plazía de grado» y «pusieron pleito firmado» para la discusión. Pero entonces surge el problema: griegos y romanos tenían lenguas distintas, «non entendrién el lenguaje non usado». ¿Cómo solucionar, pues, el problema? Sencillamente que disputasen «por señas, por señales de letrado».

El Arcipreste se vale del lenguaje no verbal para hacer una parodia del lenguaje sígnico usado en ciertos monasterios sometidos a la ley del silencio, como han estudiado, entre otros, Lecoy, María Rosa Lida y el mismo Deyermond. Dicho y hecho. Tras fijar la fecha para la contienda, los romanos con gran «coita», «porque no eran letrados», deciden que los represente un «ribald», un «vellaco», para que «según

26 Citaré por la edición de Jacques Joset, Madrid: Espasa-Calpe, 1981, 2. a ed., vol. I, págs. 27-32 (Clásicos Castellanos, n. ${ }^{\circ} 14$ ).

27 fbidem, pág. 27 , nota $46 \mathrm{~b}$. 
Dios le demostrase fazer señas con la mano / que tales las feziese» y al encontrarlo le exponen el plan:

$\ldots \ll$ Nos avemos con griegos nuestros conbid

para disputar por señas [tercera vez que sale la palabra]...».

Vistieron al «ribald» con «paños de gran valía / como si fuese dotor en la filosofía», se subió en la cátedra envalentonado, esperando al griego. Al lado, se subió en otra cátedra, «todo el pueblo juntado», el griego, un «doctor muy esmerado» $\mathrm{y}$ «començó sus señas como era tratado». He aquí el diálogo:

(55) Levantóse el griego, sosegado, de vagar, e mostró sólo un dedo que está çerca el pulgar, luego se assentó en ese mismo lugar; levantóse el ribald, bravo, de malpagar

(56) Mostró luego tres dedos contra el griego: tendidos el pulgar con otros dos que con él son contenidos, en manera de arpón los otros dos encogidos; assentóse el neçio, catando sus vestidos.

(57) Levantóse el griego, tendió la palma llana e assentóse luego con sus memoria sana; levantóse el vellaco con fantasía vana, mostró puño cerrado: de porfía a gana.

(58) A todos los de Greçia dixo el sabio griego: «Merecen los romanos las leys, non gelas niego». Levantáronse todos en paz e con sosiego; grand onra ovo Roma por un vil andariego».

Hasta aquí la gesticulación en la disputa. Veamos ahora la significación de los gestos que cada uno de los dos protagonistas realizan:

(59) Preguntaron al griego qué fue lo que dixiera por señas al romano e qué le respondiera. Diz: "Yo dixe que es un Dios; el romano que era uno en tres personas, e tal seña feziera [reproduce el gesto]

(60) Yo dixe que era todo a su voluntad; respondió que en su poder tenié el mundo, e diz verdad, Desque vi que entendién e creién la Trinidad entendí que meresçién de leyes çertenidad». 
Por su parte el bravucón romano había entendido los gestos del griego de una manera diferente:

(61) Preguntaron al vellaco quál fuera su antojo;

diz: «Díxom'que con su dedo que m'quebrantaría el ojo;

d'esto ove grand pesar e tomé grand enojo,

e respondíl'con saña, con ira e con cordojo

(62) que yo le quebrantaría ante todas las gentes con dos dedos los ojos, con el pulgar los dientes; dixom' luego após esto que le parase mientes, que $m$ 'daría grand palmada en los oídos retinientes.

(63) Yo l'respondí que l'daría a él tal puñada que en tiempo de su vida nunca la vies vengada; desque vio que la pelea tenié mal aparejada, dexóse de amanazar do non gelo preçian nada».

Nos encontramos, por lo tanto, con una clara polisemia gestual en la que los culturemas de dos pueblos distintos, simbólicamente representados por la sabiduría del griego y la estulticia del romano, hacen que, simple y dicotómicamente, unos mismos gestos sean interpretados de una manera diferente. El relato, todo lo anacrónico que se quiera, sirve de botón de muestra para lo que venimos exponiendo. Pero el hecho queda aún más claro que en la ficción literaria y ejemplar en el encuentro real entre dos culturas diferentes. Me estoy refiriendo al encuentro de la cultura europea y la indígena americana que Colón plasmó en su Diario. Españoles y aborígenes tienen que entenderse, en un principio, por señas, pero unas veces los gestos son interpretados inequívocamente por unos y otros y otras son ambiguos o mal interpretados. De ello se queja el propio Colón en alguna ocasión:

«...y también no sé la legua, y la gente d'estas tierras no me entienden, ni yo, ni otro que yo tenga, a ellos. $Y$ estos indios que yo traigo, muchas vezes les entiendo una cosa por otra al contrario» (pág. 125).

De ahí la cautela en ocasiones del Almirante ante esta polisemia gestual al afirmar a veces «según puede entender» (pág. 87), «entendía el Almirante» (pág. 168), «el Almirante entendió» (pág. 182), etc. O las quejas de los indios por no poderse entender con los recién llegados del viejo mundo: «y él [el rey] y su ayo y consejeros llevan grande pena porque no me entendían, ni yo a ellos» (pág. 157), ya que unas 
veces adivinaban los deseos de Colón a través de las señas y otras no. Pero a medida que los contactos se fueron intensificando las señas fueron mejor interpretadas, como el descubridor apostilla:

«Cada día entendemos más a estos indios y ellos a nosotros, puesto que muchas vezes hayan entendido uno por otro» (pág. 143).

«Porque por señas ya entendía algo» (pág. 182).

Sin embargo en el Diario hay un caso particularísimo de polisemia kinésica, en el que Colón no llega a interpretar correctamente, en un principio, las señas de los indios. Sucedió el lunes 3 de diciembre y nos lo cuenta del modo siguiente:

«...ayuntáronse muchos indios y vinieron a las barcas, donde ya se había recogido el Almirante con su gente toda; uno d'ellos se adelantó en el río junto con la popa de la barca y hizo una grande plática que el Almirante no entendía, salvo lo que los otros indios de cuando en cuando alçaban las manos al cielo y daban una grande voz. Pensaba el Almirante que lo aseguraban y que les plazía de su venida; pero vido al indio que consigo traía demudarse la cara y amarillo como la cera, y temblaba mucho, diziendo por señas al Almirante se fuese fuera del río, que los querían matar, y llegándose a un cristiano que tenía ballesta armada y mostróla a los indios, y entendió al Almirante que les dezía que los matarían todos, porque aquella ballesta tiraba lexos y mataba. También tomó una espada y la sacó de su vaina, mostrándosela, diziendo lo mismo. Lo cual, oído por ellos, dieron todos a huir, quedando todavía temblando el dicho indio de cobardía y poco coraçón, y era de buena estatura y rezio» (pág. 131).

Colón entiende el código gestual desde un punto de vista europeo, frente al código gestual de los aborígenes americanos, de ahí que aunque la comunicación gestual fuese el lazo primario de comunicación en la primera frase del descubrimiento entre españoles e indios y que aunque hubiese una serie de rasgos comunes entre ambas comunidades a la hora de la realización de una serie de gestos, sin embargo, en otras ocasiones se producen -como en el caso que hemos visto- diferentes interpretaciones. Y es que lo gestual - como afirma Greimas - sirve más para significar que para comunicar. Los gestos o señas significan, pero su significación es distinta a la utilizada en el código lingüístico. En éste, como es bien sabido, los significantes en general, tienen un significado concreto en un contexto determinado. En el kinésico el significante - es decir, las manifestaciones externas corporales - no tiene o puede no tener un significado concreto, ya que cada cultura tiene sus rasgos kinésicos propios, 
lo cual no quiere decir que no haya aspectos más o menos universales que se den o puedan darse en todas.

\section{LOS OJOS «HABLAN»}

El canal ocular es una de las formas más sutiles del lenguaje corporal. Dentro de los mensajes que emite el rostro, el comportamiento visual tiene una importancia capital para transmitir actitudes y sentimientos, así como para expresar, en suma, la personalidad de un individuo. Como afirmaba Jean-Paul Sartre, el contacto visual es lo que nos hace real y directamente conscientes de la presencia del otro como ser humano con conciencia e intenciones propias ${ }^{28}$. La mirada - junto con el acercamiento al otro, las posturas gestuales y la mímica- es un modo de interacción corporal. La mirada - según Dominique Picard- es uno de los elementos más significativos en la interacción y ocupa un lugar de privilegio en la relación porque su función es doble: permite a la vez expresar lo que se siente y recoger información viendo el comportamiento del otro. Varias expresiones populares traducen esa doble función: se dice de una mirada que «acaricia», que «fulmina» o que «suplica» ${ }^{29}$. Pero también de una mirada que «incomoda» o que es «insistente», pues mirar a alguien no es simplemente buscar una información sino también penetrar en su intimidad. Ser mirado se interpreta a menudo como «ser señalado», ser «el objeto» de la atención del otro, y también estar bajo el control de otro» 30 .

La mirada ha tenido una larga tradición cultural, tanto que hay numerosas leyendas a lo largo de la historia del hombre sobre el mal de ojo y los maleficios que recibe la persona que lo recibe. De ello encontramos referencias, por ejemplo, en inscripciones en tablillas de arcilla del tercer milenio a. C.; en el judío Rab en el siglo III d. C.; y hasta se decía que Pío IX —elevado al papado en 1846- era poseedor de ese

28 En El ser y la nada. Tomo la cita de F. Davis (1986: 86). Vid. entre otros, E. H. Hess, The Tell-tale Eye; how tour Eyes Reveal Hidden Throughts and Emotions (New York: Van Nostrand Reinhold, 1975).

29 Una nómina de estas expresiones se encuentran en J. Maisonneuve, «Le regard comme conduite d'interaction et sa dimension phénoménologique», en La fonction du regard (Comunicación al coloquio del INSERM, 1969), 399-414.

30 Dominique Picard, Del código al deseo. El cuerpo en la relación social (Buenos Aires: Paidós, 1986, 194). 
diabólico don, como ha estudiado certeramente Silvan Tomkins ${ }^{31}$. Como ha observado el antropólogo Edward Hall (1966), el comportamiento ocular es variado y diferente en las distintas culturas. La cultura que mayor uso hace del hablar con los ojos es la árabe, mientras que las que realizan un menor uso son las sociedades de Oriente. Veamos un ejemplo respecto al primer pueblo citado con una desorientación en la Medina de la bella ciudad marroquí de Fez, del periodista y escritor Manuel Vicent:

«La mirada es el único lenguaje de la medina de Fez... yo sabía que son los ojos de los árabes en la medina el código con que ellos se entienden, pactan y se penetran a distancia. Existen amores eternos entre adolescentes que sólo duran un guiño, aunque el combate de su mutua carne sin pudor ni culpa queda aplazado para la noche. Miradas de una contenida insinuación surgían de los rostros velados de algunas mujeres mientras te cruzabas en la calle con ellas y también estaban los ojos de la policía vigilando como secretos alcotanes y todo eso trenzaba una red de citas, amagos, deseos, calladas ofertas de intimidad que se extendía sobre el barullo de gente, pollinos y mercancías igual que en las terrazas donde se agitaba otra vida de señales amorosas y la presión de estas sensaciones la liberaba una música con ritmo de serpiente que no cesaba jamás de brotar de las guardias, armarios y tiendas presididas por el retrato de Hassan» ${ }^{32}$.

El lugar donde mira un individuo indica cual es el objeto de su atención, pero también sabemos que las miradas varían de significación de persona o persona ya que el código ocular se diversifica. Según Flora Davis (1986: 92) «los movimientos oculares de cada individuo están influidos por su personalidad, por la situación en que se encuentra, por sus actitudes hacia las personas que lo acompañan y por la importancia que tiene dentro del grupo que conversa». Todos esta casuística se podría ejemplificar con textos literarios, pero por razones de espacio nos detendremos en el examen de la mirada como atracción afectiva y sexual en dos obras muy conocidas.

Sabemos que la mayoría de los encuentros comienzan en la relación amorosa con un contacto visual. A mayor número de interacciones oculares las actitudes demostradas son más positivas, mientras que el desvío o rechazo de miradas es claro indicio de una negativa más o menos manifiesta. Ahora bien, también sabemos que la mirada no tiene en sí un efecto intrínsico, sino que su valor depende del contexto en el que ésta se realice, de ahí que a través de él pueda adquirir dos

31 S. Tomkins, Affect, Imagery, Consciousness (New York: Springer, 1962, vol. 2).

32 M. Vicent, «La medina de Fez», El Pais Semanal, 536, domingo 19 de julio (1987), 36. 
significados afectivos opuestos: la expresión de una actitud agresiva o la de una atracción afectiva, según J. Corraze (1986: 97-106).

Vamos a fijarnos en el significado sexual de la mirada cuando se produce de un modo voluntario. Para ello utilizaremos Sonata de primave$r a$ de don Ramón del Valle-Inclán ${ }^{33}$. El eje estructural del relato se articula alrededor de las relaciones de las dramatis personae: de un lado el marqués de Bradomín; de otro, María Rosario, la joven de la que queda prendado el personaje anterior; y de otro, la madre de ésta, la Princesa y sus secuaces, claros oponentes del libidinoso marqués. Por las miradas que estos tres grupos de personajes se echan, podemos llegar a calibrar el significado global del relato.

Antes todo encontramos miradas como signo de rechazo y, a veces, de agresividad. Veamos algún ejemplo. La Princesa, la madre de María Rosario, mantiene, al principio del relato, una actitud muy diplomática e interrogativa hacia Bradomín, pero a medida que el argumento avanza y se da cuenta de lo que está ocurriendo, sus miradas no pueden ser más delatoras hacia el cortejador de su hija:

«Su mirada se clavó en la mía, y sentí el odio en aquellos ojos redondos y vibrantes como los ojos de las serpientes» (pág. 278).

«Vi palidecer intensamente sus mejillas y brillar el odio en sus ojos» (pág. 291).

El mayordomo Polonio también mira al marqués con actitud negativa; tras un minucioso examen:

«Yo le adivinaba asaetándome con los ojos» (pág. 277).

«Me dirigió una mirada oblícua que me recordó al viejo Banlone, que hacía los papeles de traidor en la compañía de Ludovico Straza» (págs. 277-278).

«La voz del viejo y su mirada esquiva, despertaron en mi alma una sospecha» (pág. 295).

33 Citaré por la edición de M. Etreros, Barcelona: Plaza \& Janés, 1985, 221-307. Traté de estos aspectos en mi artículo, «Gestos y ojos "hablan" en la Sonata de primavera», en un homenaje a Valle Inclán en el cincuenta aniversario de su muerte, Revista de Estudios Hispánicos (Univ. de Puerto Rico) XVI (1989), 45-51. 


\section{También el Colegial Mayor hace otro tanto:}

«De rato en rato fijaba en mí una mirada rápida y fugaz, y yo comprendía, con un estremecimiento, que aquellos ojos negros querían leer en mi alma» (pág. 245).

Pero también el marqués, percatado de las intenciones de ellos, mira de igual modo a sus oponentes. Así, al mayordomo Polonio:

«Yo le clavé los ojos, mirándole en silencio: Me pareció que no podía dominar su inquietud» (pág. 296).

[AI no aceptar el anillo] «Yo le miré amenazador» (pág. 296).

O se producen interacciones oculares de disimulo entre Bradomín y el Colegial Mayor:

«Nos miramos de hito en hito, con un profundo sentimiento de que fingíamos por igual, y nos separamos» (pág. 246).

A través de estas miradas, Valle-Inclán viene a reafirmar una vez más los rechazos, agresividades, interrogantes y, en suma, las discordancias existentes en el plano psicológico entre los actores del relato que hacen la función de actantes oponentes, según la terminología greimasiana.

El segundo grupo de miradas lo podemos establecer en los intercambios oculares que Xavier de Bradomín dirige a su idealizada María Rosario. Este don juan «feo, católico y sentimental» - muy al estilo del seductor italiano de Da Ponte- tiende las garras de la seducción hacia la bella joven destinada al servicio religioso. Sus miradas hacia ella son conscientes, insistentes y —cómo no- místicamente ardientes:

«Yo escuchaba distraído, y desde el fondo de un sillón, oculto en la sombra, contemplaba a María Rosario. Parecía sumida en un ensueño: Su boca pálida de ideales nostalgias permanecía anhelante, como si hablase con las almas invisibles, y sus ojos inmóviles abiertos sobre el infinito, miraban sin ver. Al contemplarla, yo sentía que en mi corazón se levantaba el amor ardiente y trémulo como una llama mística» (pág. 248-249). 
Por su parte, María Rosario también mira seductora-seducida a su galán de turno y no con malos ojos. Ahora bien, su condición de mujer, debido a una educación tradicional, hace que deba reprimir sus impulsos oculares hacia el hombre que la corteja, máxime cuando la senda religiosa elegida se lo impide aún más. Su actitud es como la de un meandro. Son varios los tipos de miradas que en ella se manifiestan. Uno, primero, de adicción o muestra de simpatía:

«Creo que además de sus labios me sonrieron sus ojos» (pág. 232).

«Y aquellos ojos como no he visto otros hasta ahora, ni los espero ver ya, tuvieron para mí una mirada tímida y amante. Callábamos conmovidos» (págs. 300-301).

Como hay una cierta adicción por el caballero mirón, la joven le echa a veces miradas furtivas:

«Seguí andando con los ojos fijos en aquella feliz aparición. Al ruido de mis pasos alzó levemente la cabeza, y con dos rosas de fuego en las mejillas volvió a inclinarla, y continuó leyendo... Al cabo de un momento volvió a levantar la cabeza, y sus ojos, en un batir de párpados, echaron sobre mí una mirada furtiva» (p. 283).

Pero cuando se da cuenta de lo que está realmente ocurriendo en el interior del marqués, opta por tomar tres actitudes diferenciadas. No se atreve a mirar a sus seductor:

Interrogó sin osar mirarme... y quedó con los ojos fijos en el cristal de la fuente» (pág. 284).

«Yo acudí presuroso a levantar el cortinaje de la puerta. María Rosario pasó con los ojos bajos, sin mirarme... Y con el alma herida por el desdén que María Rosario me mostrara, volví al estrado» (págs. 244-245).

Ante la cruda realidad de la adicción amorosa de Bradomín por ella, sus miradas hacia él son de horror, de espanto, de susto:

«Y miré a María Rosario, que bajó la cabeza y se puso encendida como una rosa... Miré disimuladamente a María Rosario: Sus hermosos ojos negros me contemplaban asustados» (pág. 259).

«...Se detuvo bajo la lámpara y me miró con ojos asustados, enrojeciendo de pronto. Luego quedó pálida, pálida como la muerte» (pág. 248). 
«Estaba pálida, y juntaba las manos mirándome con sus hermosos ojos angustiados» (pág. 285).

«Me miró despavorida, como si al sonido de mi voz se despertase, y arrancándose de mis brazos huyó hacia la ventana» (pág. 299).

«...Y me clavó los ojos, tristes, suplicantes, guarnecidos de lágrimas como de oraciones purísimas» (pág. 302).

Y la tercera actitud es la de cerrar los ojos:

«María Rosario cerraba los ojos con espanto, como al borde de un abismo» (pág. 298).

A través de estos repertorios visuales podemos constatar que el eje semántico del relato queda explícitamente más reforzado. En síntesis, la Princesa y sus adictos (Polonio, el Colegial Mayor, etc.) se oponen a los proyectos libidinosos de Xavier de Bradomín a través de las miradas inquisitoriales y negativas que echan al marqués; María Rosario, en su pasividad reprimida y en medio del torbellino, no mira con malos ojos a su seductor hasta enloquecer al final; y al narrador-narrado en este fragmento de memorias que es Sonata de primavera se le vuelven los ojos chispas hacia la joven idealizada platónicamente. Valle-Inclán se sirve del lenguaje de los ojos como un elemento reforzador, desde el punto de vista psicológico, de las emociones y sentimientos que narra y describe.

El otro ejemplo - podrían ser miles- que quisiera presentar tiene un matiz algo distinto. Se trata de un lenguaje de ojos más insinuador, evanescente y a distancia que encontramos en el epígrafe [13] —según la numeración del traductor, José María Valverde- del Ulises, del irlandés y padre de la novelística moderna, James Joyce ${ }^{34}$.

La escena se desarrolla en la playa, al atardecer, entre las ocho y las nueve. De un lado encontramos a Gerty Maclowell, «sumergida en sus pensamientos, con la mirada perdida allá en lontananza, era, a decir verdad, un ejemplar del joven encanto irlandés tan bello como cupiera desear... Su tipo era esbelto y gracioso... La palidez cérea de su rostro era casi espiritual en su pureza marfileña, aunque su boca de capullo era un auténtico arco de Cupido, de perfección helénica...» (pág. 531); y junto a ella sus amigas Cissy Cafrey — con sus dos hermanos gemelos

34 J. Joyce, Ulises (Barcelona: Lumen, 1976, t. I, 528-577). 
de apenas cuatro años, Tommy y Jacky - y Edy Boardman - con su hermanito, un bebé de once meses y nueve días en el cochecitoGerty, toda de azul, incluso su ropa interior, «su color preferido, y el color de suerte también para casarse que la novia tiene que llevar un poco de azul en alguna parte» (pág. 535), está sumida en pensamientos hacia aquel chico, estudiante, que andaba siempre en bicicleta de un lado para otro delante de su ventana. Joyce, en la primera parte de esta unidad narrativa, dirige el foco narrativo, fundamentalmente, hacia lo que está ocurriendo en este lado de la playa. En el otro, estaba un señor sentado enfrente del grupo. El enlace narrativo de lo que pasa al uno y al otro lado surgirá a través de la pelota con la que los gemelos juegan. Cissy la echa por la arena y aquélla va a parar a donde está el hombre solitario. Gerty, mientras tanto, «envuelta en sus pensamientos, apenas veía u oía a sus compañeras ni a los gemelos en sus pueriles cabriolas ni al señor llegado de Sandymount Green al que Cissy Caffrey le llamaba ese hombre que se parecía tanto a su padre» (pág. 539), aunque no era borracho. Pero a Gerty no le gustaría como padre «porque era demasiado viejo o no sabía por qué o por causa de su cara (era un caso palpable de antipatía a simple vista) o su nariz forunculosa con sus verrugas y su bigote color arena un poco blanco debajo de la nariz» (pág. 539). Leopold Bloom, vestido de negro, recoge la pelota, intenta devolvérsela a Cissy, pero ésta se detiene debajo mismo de la falta de Gerty. Ésta intenta devolverla con una patada, pero falla. Hace un segundo intento más, para lo que «se levantó la falda un poquito pero justo lo suficiente» (pág. 541), lanzando la pelota bastante lejos y anota el narrador: «no era nada más que para llamar la atención teniendo en cuenta al caballero de enfrente que miraba» (pág. 541). Empieza el flirteo entre ambos a través de los ojos. «Ella sintió el cálido sofoco, siempre una señal de peligro en Gerty MacDowell, subiendo y ardiéndole en las mejillas. Hasta entonces sólo habían intercambiado ojeadas del modo más casual pero ahora bajo el ala de su sombrero nuevo ella se atrevió a mirarle y la cara que se ofreció a su mirada allí en el crepúsculo, consumida y extrañamente tensa, le pareció la más triste que había visto jamás» (pág. 541-542).

El juego de miradas a partir de entonces y por parte de ambos iba a ser explícito y continuo, como el relato confirma:

«Sí, era ella a quien miraba él y su mirada quería decir muchas cosas. Sus ojos ardían en ella como si la explorara por dentro, toda, leyendo en su misma alma. Maravillosos ojos eran, espléndidamente expresivos, pero ¿se podía fiar una de ellos? La gente era muy rara. Vio enseguida por sus ojos oscuros y su pálido rostro intelectual que era un extranjero... pero ella no 
veía si tenía nariz aguileña o un poco remangada desde donde estaba sentado. Iba de luto riguroso, ya lo veía, y en su rostro estaba escrita la historia de un dolor acosador. Habría dado cualquier cosa por saber qué era. Miraba tan atentamente, tan quieto y la vio dar la patada a la pelota y a lo mejor veía las brillantes hebillas de acero de sus zapatos... Ahí estaba lo que ella había soñado tantas veces. Era él el que contaba y su rostro se llenó de alegría porque le quería porque sentía instintivamente que era diferente a todos. Su corazón mismo de mujer-muchacha salía al encuentro de él, su marido soñado, porque al instante supo que era él» (págs. 543544) [y estaba dispuesta a perdonárselo todo.]

Mientras, su amiga, más bien rival, Cissy pasaba corriendo delante del enlutado caballero con el intento de lucirse y llamar la atención del solitario, agarrando a los dos gemelos:

«...y buenas ganas tenía de darles unos cachetes ruidosos pero no lo hizo porque pensó que él pódía estar mirando pero nunca en su vida cometió una equivocación mayor porque Gerty veía sin mirar que él no le quitaba los ojos de encima...» (pág. 546).

En lo que se fijaba Leopold Bloom era en otra cosa: en las medias transparentes que llevaba Gerty:

«...eso era lo que miraba él, transparentes, y no a esas otras insignificantes que no tenían forma ni figura (¡qué cara dura!) porque tenía ojos en la cara para ver él mismo la diferencia» (pág. 546).

Gerty se quita el sombrero para arreglarse el pelo con «una breve visión radiante» (pág. 547), mientras las interacciones visuales se suceden:

«Casi pudo ver el rápido sofoco en respuesta admirativa de los ojos de él, que la hizo vibrar en todos sus nervios. Se puso el sombrero para poder mirar por debajo del ala y balanceó más rápido el zapato con hebilla pues se le cortó el aliento al captar la expresión de sus ojos. Él la observaba como la serpiente observa a su víctima. Su instinto femenino le dijo que había provocado un tumulto en él y al pensarlo un ardiente escarlata la invadió desde el escote a la frente hasta que el delicioso color de su rostro se convirtió en un glorioso rosado» (pág. 547).

Pero también su amiga Edy Boardman se había dado cuenta del hecho, «porque miraba de reojo a Gerty... fingiendo arreglar al nene» (pág. 547). Gerty tenía unas terribles ganas de que el asunto acabara e 
insinuó a su amiga marcharse. Cissy quiere saber la hora exacta y va a preguntársela al caballero solitario:

«Así que allá que fue y cuando él la vio le vio que se sacaba la mano del bolsillo, y se ponía nervioso, y empezaba a jugar con la cadena del reloj, mirando a la iglesia. Aunque de naturaleza apasionada Gerty vio que tenía un enorme dominio de sí mismo. Hacía un momento estaba allí fascinado por una delicia que le hacía mirar pasmado, y un momento después ya era el tranquilo caballero de grave rostro, con el dominio de sí mismo expresado en todas las líneas de su rostro distinguido» (págs. 547-548).

Cissy le pregunta a Bloom la hora, pero éste al ir a decírsela ve que se le ha parado el reloj. Gerty no quita ojo:

«...ella vio al caballero dando cuerda al reloj y oyendo si funcionaba y ella balenceó más la pierna entrando y saliendo a compás. Estaba oscureciendo pero él podía ver y miraba todo el tiempo mientras daba cuerda al reloj o lo que estuviera haciendo y luego se lo volvió a guardar y se metió las manos otra vez en los bolsillos. Ella sintió una especie de sensación que la invadía y comprendió por cómo notaba la piel del pelo y esa irritación contra la faja que debía venirle esa cosa porque la última vez fue también cuando se cortó las puntas del pelo porque tocaba lo de la luna. Los oscuros ojos de él se volvieron a fijar en ella, bebiendo todos sus perfiles, literalmente adorándola en su santuario. Si ha habido alguna vez una admiración sin disimulo en la apasionada mirada de un hombre, ahí se veía claramente, en el rostro de ese hombre. Es por tí, Gertrude MacDowell, y lo sabes muy bien» (pág. 548-549).

Empieza a prepararse para marcharse. Las amigas punzan a Gerty sobre el estudiante que la dejó plantada. Ante lo cual, «Un rápido fulgor frío brilló en sus ojos, expresando elocuentemente un inmenso desprecio» (pág. 549). A punto estuvo de llorar. Mientras:

«...Ellas la miraban en inexorable escrutinio, pero, con un valeroso esfuerzo, Gerty volvió a chispear en respuesta comprensiva, lanzando una ojeada a su nueva conquista para que vieran» (pág. 549).

Respondiendo con decisión:

«... puedo arrojar el guante a cualquiera porque es año bisiesto» (p. 549). 
Con ella no se podía jugar y estaba dispuesta a dejar de lado al señorito Reggy: «Y si se le ocurría jactarse alguna vez, ella le dejaría clavado en su sitio con Wyle, una mirada de medio desprecio» (pág. 550). Gerty - pese a su «defecto que ella sabía no tendría por qué tener a ninguna competidora y eso fue un accidente bajando la cuesta de Dalkey y siempre trataba de ocultarlo» (p. 552) - estaba ya dispuesta a todo con aquel caballero mirón y se daba cuenta:

«Pero tenía que terminar, lo presentía. Si distinguía en los ojos de él esa mágica llamada, no habría nada que la sujetara. El amor se ríe de las rejas. Ella haría el gran sacrificio. Su único empeño sería compartir los pensamientos de él» (pág. 552).

Elocubra si era casado o viudo, mas no quería ser como una de esas prostitutás; sería mejor tener una relación de hermanos... De pronto se encienden a lo lejos fuegos artificiales y todo el grupo baja a la playa a verlos; pero Gerty permanece inmóvil y

«...dijo que veía muy bien desde donde estaba. Los ojos que estaban clavados en ella le hacían hormiguear las venas. Le miró un momento, encontrando su mirada, y una luz la invadió. En aquel rostro había pasión al rojo blanco, una pasión silenciosa como la tumba, que la había hecho suya» (pág. 553).

Y ya sin nadie, solos los dos, reaccionan ambos de la manera siguiente:

"Al fin quedaban solos sin las otras que cotillearan y comentaran y ella sabía que podía confiar en él hasta la muerte, constante, un hombre de ley un hombre de honor inflexible hasta la punta de los dedos. A él le vibraban las manos y la cara, un temblor la invadió a ella. Gerty se echó muy atrás para mirar desde lo alto los fuegos artificiales y se cogió la rodilla entre las manos para no caerse atrás al mirar y no había nadie que lo viera sino sólo él y cuando reveló así del todo sus graciosas piernas, tan hermosamente formadas, tan flexibles y delicadamente redondeadas, le pareció oír el jadeo de su corazón, el ronco respirar de él, porque conocía la pasión de hombres así, de sangre caliente, porque Bertha Supple se lo había contado...» (págs. 553-554).

Leopold Bloom se masturbaba ante la visión para él erótica: 
«...y Jacky Caffrey gritó que miraran, que había otro y ella se echó para atrás y las ligas eran azules haciendo juego por lo de la transparencia y todos lo vieron y gritaron mira, mira ahí está y ella se echó atrás todavía más para ver los fuegos artificiales y algo raro volaba por el aire, una cosa suave de acá para allá, oscura. Y ella vio una larga bengala que subía por encima de los árboles, arriba, y en el tenso silencio, todos estaban sin aliento de la emoción mientras subía más y más y ella tuvo que echarse todavía más y más atrás para seguirla con la mirada, arriba, arriba, casi perdiéndose de vista, y tenía la cara invadida de un divino sofoco arrebatador de esforzarse echándose atrás y él le vio también las otras cosas, bragas de batista, el tejido que acaricia la piel, mejor que esas otras de pantalón, las verdes, cuatro con once, porque eran blancas y ella le dejaba y vio que veía y luego subía tan alto que se perdió de vista por un momento y ella temblaba por todo el cuerpo de echarse tan atrás y él lo veía todo bien arriba por encima de la rodilla que nadie jamás ni siquiera en el columpio ni vadeando con los pies en el agua y a ella no le daba vergüenza y a él tampoco de mirar de ese modo sin modestia porque él no podía resistir la visión de la prodigiosa revelación ofrecida a medias como esas bailarinas de falditas cortas que se portaban tan sin modestia delante de los caballeros que miraban y él seguía mirando, mirando. Ella habría deseado gritar hacia él con voz sofocada, extender sus brazos níveos para que vinera, sentir sus labios en la blanca frente, el clamar de un amor de muchacha, un gritito ahogado, arrancado de ella, ese grito que corre a través de los siglos. Y entonces subió un cohete y pam un estadillo cegador y ¡Ah! luego estalló la bengala y hubo como un suspiro de ¡Ah! y todo el mundo gritó ;Ah! ;Ah! en arrebatos y se desbordó de ella un torrente de cabellos de oro en lluvia y se dispersaron y $i \mathrm{Ah}$ ! eran todos como estrellas de rocío verdoso cayendo con doradas ¡Ah qué bonito! 1Ah qué tierno, dulce, tierno!» (págs. 554-555).

Tras el espectáculo de los cohetes, sobreviene el silencio:

«ella le lanzó una ojeada al echarse adelante rápidamente, una pequeña ojeada patética de protesta lastimosa, de tímido reproche, bajo la cual él se ruborizó como una muchacha. Él estaba recostado contra la roca de detrás» (pág. 555).

Leopold Bloom, «ante esos jóvenes ojos sin malicia», siente remordimientos por lo hecho, pero sabe que «había una infinita reserva de misericordia en aquellos ojos» (pág. 555). El secreto sería de los dos. Gerty antes de irse deja caer un algodón con perfume y:

«sus almas se unieron en una última ojeada demorada, y los ojos de él alcanzándole el corazón, llenos de un fulgor extraño, quedaron flotando en arrebato en torno a su dulce rostro floreal... Lentamente sin mirar ella bajó por la playa desigual...» (pág. 556). 
Ella se aleja cojeando. A través de este pasaje se pone de manifiesto una verdadera comunicación a través de un lenguaje muy particular: el de los ojos. Por medio de las miradas se produce una seducción a distancia, en la que cada uno de los dos interlocutores interpreta los signos de una manera diferente pero paralela. Gerty, de un modo romantico y de novela rosa, y Leopold de una manera erótica. Y como éste reconoce explícitamente «había una especie de lenguaje entre nosotros» (pág. 563).

\section{OTROS ASPECTOS}

Podríamos seguir analizando, además de otros gestos, las maneras y las posturas. Así como rasgos de la proxémica definida por Fernando Poyatos como «el concepto, estructuración y uso del espacio, desde el entorno natural, modificado o construido por el hombre hasta las distancias mantenidas consciente o inconscientemente en la interacción personal. Es decir, la conducta próxémica abarca muchas manifestaciones universales y culturales, pero en primer lugar son biológicas, o sea, las desarrolladas por nosotros como organismos que exigen, delimitan y mantienen un territorio propio u ocupan el ajeno. Como sistema comunicativo de origen corporal desarrollado en la interacción, la conducta proxémica se estructura con otras actividades portadoras de mensajes, desde el lenguaje verbal y el paralenguaje hasta el contacto físico y la percepción olfativa ${ }^{35}$, afectadas todas ellas por cada una de las cuatro distancias clasificadas por Hall (pública, social, personal e íntima). Dentro de la narrativa la conducta proxémica puede revelar no solo un concepto psicológico concreto, sino el medio cultural en el que se desarrolla la acción (lo cual caería en la antropología literaria...), ya que los conceptos "distancia personal" y "distancia íntima" pueden variar sensiblemente de una cultura a otra», según Poyatos (1976: 358, nota 5). También se podía estudiar la cronémica, definida por el citado investigador» como área de estudio que trataría la conceptualización y uso del tiempo como elemento biopsicológico y cultural que proporciona características especiales a las relaciones sociales y a las actividades comunicativas en general, desde sílabas lingüísticas y gestos inconscientes hasta miradas cargadas de significado y elocuen-

35 Al respecto sería muy interesante realizar un estudio sobre la excelente novela de Patrick Süskind, El perfume (Barcelona: Seix Barral, 1986). 
tes silencios (Poyatos, 1976: 358, nota 6). Es decir, en una narración podemos analizar no sólo el tiempo social (el utilizado en las relaciones sociales que varía según la cultura, aparte de ciertas características universales). sino el tiempo interactivo (utilizado en las diversas formas de encuentros interactivos y en la producción de las actividades comunicativas mismas), e incluso el tiempo conceptual (pues, según la cultura y la personalidad, varían conceptos como puntualidad e impuntualidad, unos minutos, media hora, hasta luego, pronto, etc.» ${ }^{36}$ ).

\section{FINAL}

Termino ya. Es cierto que la comunicación no verbal existe en la interacción personal entre dos o más interlocutores y que está estrechamente ligada con la comunicación verbal. Según Knapp (1982), existen numerosos puntos de contacto entre los dos sistemas: puede servir lo no verbal para reforzar lo verbal, para sustituirlo, para complementarlo, para poner énfasis en algún aspecto, para repetirlo o para regular el flujo comunicativo. Para S. Johnson y M. Gentleman ${ }^{37}$ hay cinco modos de interrelación entre lo verbal y lo no verbal: para acrecentar en el canal auditivo componentes no verbalizados, para sustituir a lo verbal, para contradecir un comportamiento verbal simultáneamente, para complementar a éste último y para producir, a veces, ciertos obstáculos o ruidos en la comunicación cuando los comportamientos no verbales no son bien entendidos.

Ahora bien, si en la comunicación oral la sistematización de los repertorios extraverbales es fácilmente observable, en la literatura la cosa se complica. En principio no podrían darse por ser una comunicación indirecta, a distancia. En el lenguaje escrito - como es lo literario, en general- lo no verbal tiene que ponerse de manifiesto, explícitamente, por medio de signos impresos (visuales), aunque implícitamente el creador ofrece al lector una serie de posibilidades multisensoriales que éste podrá revivir y re-crear en mayor o en menor cuantía según sea su competencia. En la literatura, desde un punto de vista semiótico, los signos visuales, olfativos, táctiles, cines-

36 Sobre los silencios en la novela cf. Poyatos (1976: 358-359, nota 7). Sobre los silencios del lector vid. Lisa Block de Behar, Una retórica del silencio. Funciones del lector y procedimientos de la lectura literaria (México: Siglo XXI, 1984).

${ }_{37}$ Cito por M. Rector y A. R. Trinta (1985: 37-47). 
tésicos, auditivos o gustativos se reducen a otros exclusivamente visuales. Aquí es donde viene la dificultad y la grandeza del arte verbal por excelencia. En la comunicación literaria los repertorios extraverbales, gracias a un proceso de metamorfosis, están virtualmente presentes a través de la creación y la re-creación de los personajes de los textos (muy especialmente en la novela, el cuento y la épica), como hemos intentado exponer. $\mathrm{Y}$ estos repertorios no verbales tienen una gran importancia tanto técnica como estilística, muy especialmente para fijar realismos de diversa factura (realismo físico, deformante, individualizador, psicológico, interactivo o documental, según Poyatos). Para el escritor es un gran desafío describir los comportamientos no verbales de sus dramatis personae y tendrá que poner mucha agilidad en su pluma para conseguir proporcionar al lector, a través de ellos, unas pautas definitorias de los mismos. Lo literario es un acto lingüístico que representa, ficcionalmente a personas, hechos, lugares, etc. El autor reproduce lo que otros imaginariamente dicen y al hacerlo está realizando una serie de citas ${ }^{38}$ de una serie de diversos lenguajes. Lenguajes que, según Bajtín ${ }^{39}$ conviven en el texto literario en relación dialógica. Así pienso que habría que ver los repertorios no verbales en la comunicación literaria: como un lenguaje más en «diálogo» continuo con otros lenguajes que articulan en su totalidad la polifonía textual.

\section{Referencias bibliográficas}

Bernard, M. (1972). Le corps. París: Editions Universitaires.

Birdwhistell, R. L. (1952). Introduction to Kinesics. An Annotation System for Analysis of Body Motion and Gesture. Washington: Foreing Service Institute/Department of State.

- (1973). Kinesics and Context. Harmondsworth: Penguin.

Bouissac, P. (1973). La mésure des gestes. Prolégomènes à la sémiotique gestuelle. La Haya: Mouton.

Bourdieu, P. (1977). «Remarques provisoires sur le perception sociale des corps». Actes de la Recherche en Sciences Sociales 14 (abril).

CORRAZE, J. (1986). Las comunicaciones no verbales. Madrid: G. Núñez Editor.

DARWIN, CH. (1955). The Expression of Emotions in Man and Animals. Nueva York: Philosophical Library.

38 Ver al respecto el excelente libro de Graciela Reyes, Polifonía textual. La citación en el relato literario (Madrid: Gredos, 1984).

39 M. Bajtín, The dialogic imagination (Austin: University of Texas Press, 1981). 
DAVIs, F. (1986). La comunicación no verbal. Madrid: Alianza.

DAvis, M. (1972). Understanding body Movements. Bloomington: Indiana University Press.

Davis, M. y SkUPIEN, J. (1982). Body Movement and Nonverbal Communication: An Annotated Bibliography, 1971-1981. Bloomington: Indiana University Press.

EFron, D. (1972). Gesture. Race and Culture. La Haya: Mouton.

FAST, J. (1971). El lenguaje del cuerpo. Barcelona: Kairós.

Giocchiara, G. (1977). Il linguaggio del gesto. Palermo: Sellerio (Introducción de S. Miceli).

Gorden, R. L. (s. a.). American Gest in Colombian Homes: A Study of Crosscultural Communication. Cambridge: Cambridge University Press.

- (1974). Living in Latin America. National Texbook Company.

HALl, E. T. (1959). The Silent Language. Nueva York: Doubleday.

- (1966). The Hidden Dimension. Nueva York: Doubleday.

- (1976). Beyond Culture. Garden City/Nueva York: Anchor/Doubleday.

KANY, Ch. E. (1960). American-Spanish Euphemism. Berkeley. [«Apendix II: Gestures»].

Kendon, A. (1975). Organitation of Behavior in Face-to-face Interaction. La Haya: Mouton.

Kendon, A., ed. (1981). Nonverbal Communication, Interaction and Gesture. La Haya: Mouton.

KNAPP, L. M. (1982). La comunicación no verbal. El cuerpo y el entorno. Barcelona: Paidós.

Marqués, J. V. (1987). «Un lenguaje desconocido». El País Semanal, domingo 25 de enero, 61.

MAURo, T. DE 1986). Minisemántica. Sobre los lenguajes no verbales y sobre las lenguas. Madrid: Gredos.

Moreno Villa, J. (1940). Cornucopia de México. México: Casa de España.

Noth, W. (1985). Handbuch der Semiotik. Stuttgart: J. B. Metzler.

Poyatos, F. (1976). «Nuevas perspectivas de la narración a través de los repertorios extraverbales del personaje». En Teoría de la novela, VV.AA., 353-383. Madrid: SGEL.

- (1981). «Punctuation as Nonverbal Communication: Toward an Interdisciplinary Approach to Writing». Semiótica 34, 1/2. 91-112.

- (1983). New Perspectives on Nonverbal Communication: Studies in Cultural Anthropology, Social Psychology, Linguistics, Literature, and Semiotics 3. Oxford: Pergamon Press (cap. V).

- (1985). «Antropología literaria: la narración como fuente interdisciplinar de signos culturales sensibles e inteligibles». En Teoria semiótica. Lenguajes y Textos hispánicos. M. Á. Garrido (ed.), 366-391. Madrid: CSIC.

RECTOR, M. y Trinta, A. R. (1985). Comunicação não-verbál: A gestualidade brasileira. Petrópolis: Vozes.

SAITZ, R. L. (1972). Handbook of Gestures: Colombia and the United States. La Haya: Mouton.

SÁNCHEZ DE ZAVALA, V. (1973). Indagaciones praxiológicas sobre la actividad lingüística. Madrid: Siglo XXI.

SAPIR, E. (1962). El lenguaje. Introducción al estudio del habla. México: FCE, $2 .^{a} \mathrm{ed}$.

SERrano, S. (1980). Signos, lengua y cultura. Barcelona: Anagrama. 
TorRego, E. (1971). «Lingüística y cinésica». Revista de Filología Española LIV, 145-159.

Walfgang, A., ed. (1984). Nonverbal Behavior: Perspectives, Applications, Intercultural Insights. Toronto: C. J. Hogrefe.

WUNDT, W. (1973). The Language of Gestures. La Haya: Mouton.

Zilio, G. M. (1960). El lenguaje de los gestos en el Río de la Plata. Montevideo. 